\title{
RESISTING ERASURE: THE POLITICS OF RECKONING WITH STATELESSNESS IN THE ARTS
}

\author{
NiCOLETTA ENRIA* \\ TABLE OF CONTENTS
}

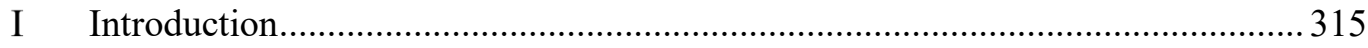

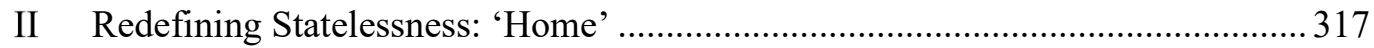

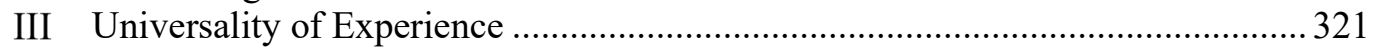

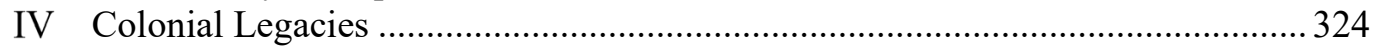

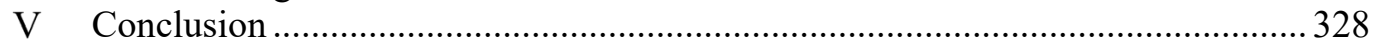

\section{INTRODUCTION}

After this I disappeared...

But I didn't die.

Isn't there a lesson in this?

- Alien Land, Mo'min Swaitat ${ }^{1}$

This quote from Alien Land, a play by one of my interlocutors, Mo'min Swaitat, a Bedouin actor from Palestine, captures how stateless people often slip through the cracks and remain invisible. Statelessness is the condition of individuals, populations or spaces that are not legally bound to a state. Here, I focus on stateless populations, namely those who are 'recognised as belonging to an entity and/or ethnicity which has no state'. ${ }^{2}$ The popular and policy discourse on statelessness remains dominated by legal-bureaucratic jargon, codifying stateless people as defined by negatives. ${ }^{3}$ Not only does this make the discourse inaccessible to a large portion of the affected populations, the disempowering traits of defining statelessness as a 'curse' that must be eradicated discourages stateless actors from

* Nicoletta Enria conducted this research as part of her postgraduate studies at the London School of Economics and Political Science's European Institute. Her research focus and interests lie in European Union migration and asylum policy; statelessness; European, Middle Eastern and North African ('MENA') politics and fostering the arts for empathetic policymaking. She has a background in advocacy and policy in minority rights and EU-MENA and Euro-Mediterranean relations, and is currently working as an analyst in EU justice and home affairs.

1 Mo'min Swaitat, Alien Land (Play Script, 2018), 14 (copy on hand with the author) ('Alien Land').

2 Amal de Chickera and Laura van Waas, 'Unpacking Statelessness' in Tendayi Bloom, Katherine Tonkiss and Phillip Cole (eds), Understanding Statelessness (Routledge 2017) 54, 65.

3 See, eg, Convention Relating to the Status of Stateless Persons, opened for signature 28 September 1954, 360 UNTS 117 (entered into force 6 June 1960) art 1 ('1954 Convention'): A stateless person is an individual 'who is not considered as a national by any State under the operation of its law'. 
taking part in the conversation at all. ${ }^{4}$ Yet, with this approach to statelessness in mind, I was curious to discover how artists sought to advocate for the elimination of statelessness through their artwork, as an alternative to the inaccessibility of the policy space. I was then taken aback that, in fact, Swaitat's 'lesson in this' was not that at all. Rather than fighting to eradicate the 'curse' of statelessness, artists today are actively deconstructing and shifting the understandings of what it means to be stateless - resisting erasure rather than creating a movement shining a light on their invisibility. To underline the relevance of paying attention to statelessness in the arts, I will discuss my research with stateless art interlocutors, and show how I found them to use art to promote empathy for the issue. I refer to them as 'art interlocutors', a term coined by Jessica Winegar, to stress the importance of discussion in artists' lives and work. ${ }^{5}$

Firstly, what do we understand 'art' to mean? The arts, here, refers to literary, visual and performative creative products that play a fundamental role into our understanding of how we see society. John Berger argued that we never just look at art, but we always situate ourselves in it, thus exploring the relation between the object and ourselves. ${ }^{6}$ Berger gives a useful example of how, when we look at paintings that represent femininity this influences our understanding of masculinity, thus consolidating perceptions of gendered difference. ${ }^{7}$ Whilst this provides an outdated binary understanding of gender, it helps shed light on how the arts provide fertile ground to sew exclusion into (or out of) society's fabric. It is an accessible medium available to oppressed communities to take control of how they are represented. ${ }^{8}$ Additionally, novelist Leo Tolstoy claimed that the role of art is to transmit one's emotions so that the reader feels that they too have experienced them. ${ }^{9}$ Thus, the arts are a powerful tool to transmit experiences empathetically. By empathy, we understand a 'process in which one person imaginatively enters into the experiential world of an other', which enables 'the creation of interpersonal ... spaces in which similarities and differences can be mobilised, expressed and explored'. ${ }^{10}$ This is in opposition to sympathy, as the feeling of sadness or happiness for someone, underlining a distanced concern for the other's welfare. ${ }^{11}$ Therefore, empathy here can be seen as an effective tool to humanise stateless subjects, usually dehumanised in their forced invisibility. So, I found art exploring statelessness to give stateless actors the opportunity to participate in the public debate, in which they are normally voiceless, aiding an empathetic connection.

For my research, I conducted interviews with artists from stateless nations including Palestine, Kurdistan, Azawad and Balochistan based in London, Paris and Berlin. I sought to understand how stateless art interlocutors reckon with the

4 Ending Statelessness within 10 Years (Special Report, United Nations High Commissioner for Refugees 2018) <http://www.unhcr.org/ibelong/special-report-ending-statelessnesswithin-10-years/>.

5 Jessica Winegar, Creative Reckonings: The Politics of Art and Culture in Contemporary Egypt (Stanford University Press 2006) 10.

6 John Berger, Ways of Seeing (Penguin 2008) 9.

7 ibid 47.

8 Jeremy MacClancy, Contesting Art: Art, Politics and Identity in the Modern World (Berg 1997) 2.

9 Leo Tolstoy, What is Art? (Oxford University Press 1969), 169.

10 Liz Bondi, 'Empathy and Identification: Conceptual Resources for Feminist Fieldwork' (2003) 2(1) ACME: International Journal of Critical Geography 64, 71, 67.

11 Heidi L Maibom, '(Almost) Everything You Ever Wanted to Know About Empathy' in Heidi L Maibom (ed), Empathy and Morality (Oxford University Press 2014) 1, 3. 
concept of statelessness in Europe. Here I adopt Winegar's usage of the term 'reckoning' to highlight agentive qualities and capture how people deal with something that appears to have been already set. ${ }^{12}$ In this piece I highlight the strategies adopted by the art interlocutors and how these then foster empathy. I show how the title of 'statelessness' is rejected and reshaped to become more relatable in terms of home and belonging. Then, I focus on how stateless art interlocutors explore the universality of experience, and redefine boundaries between stateless and non-stateless people. Finally, I explore how these stateless art interlocutors build a dialogue with Europe, subverting a discourse that silenced and oppressed them. These methods and thematic shifts underline the main empirical finding that stateless art interlocutors reckon with statelessness by fostering empathy, rather than sympathy.

\section{REDEFINING STATELESSNESS: 'Home'}

Fascinatingly, most stateless art interlocutors, expressed significant disapproval of the term 'statelessness'. The 1954 Convention Relating to the Status of Stateless Persons definition, of a stateless person as an individual 'who is not considered as a national by any State under the operation of its law', remains the only internationally-accepted definition. ${ }^{13}$ Thus, a powerful tool in stateless art interlocutors' arsenals, is that of refuting this literal meaning of 'statelessness', and redefining it on their own terms, based on the borderless, universal concept of 'home'. So, as participants try to navigate between identifying as stateless, and defining their experiences which are more complex and nuanced, how do they contest the term?

Firstly, 'statelessness' is refuted as something that marks stateless actors as inherently 'Other'. Palestinian photographer Ahlam Shibli claimed that she far prefers the term 'homelessness'. It is worth noting that here 'home' refers to the conceptual understanding of a place where one feels one belongs, rather than a place of residence. Shibli explores this in her project Staring where she exhibits photographs taken in Kassel (Germany) and Al-Khalil/Hebron (Palestine) exploring the struggle to establish a 'home' from radically different perspectives. ${ }^{14}$ In Kassel, the photographs show immigrants engaging in community-based activities, placed aside images of Palestinian homes scattered nearby Israeli watchtowers and prisons. With this, Shibli shows how 'home' isn't solely a problem for stateless populations, creating an empathetic space, where conversation can flourish exploring the similarities and differences whilst communicating respect and recognition.

12 Winegar (n 5) 6.

131954 Convention (n 3).

14 Ahlam Shibli, Staring: Nine Episodes from Al-Khalil/Hebron (Palestine) and Kassel (Germany) (Photo Collection, Remai Modern 2016) <https://remaimodern.org/field/webcommissions/ahlam-shibli-staring $>$. See also Figs 1, 2. 


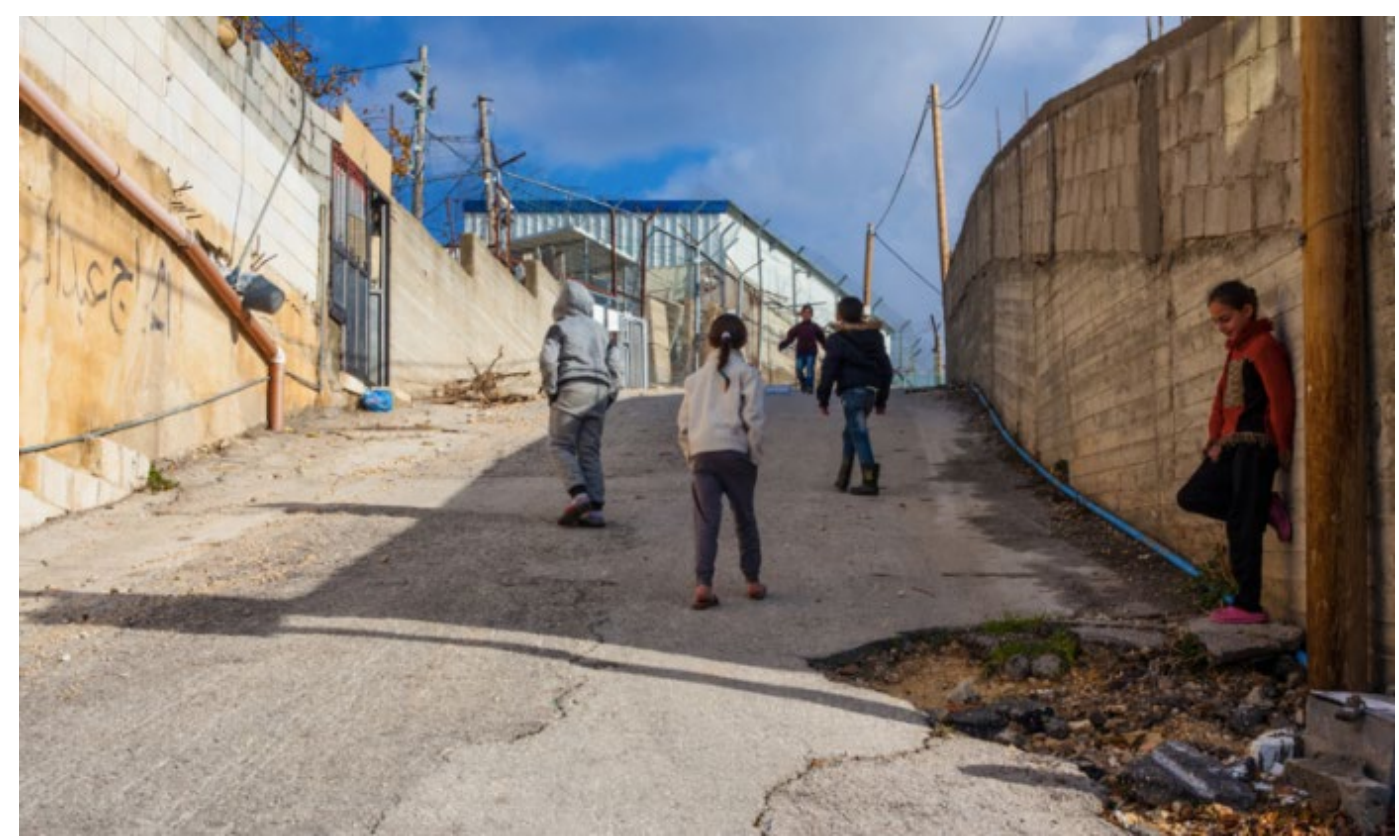

Figure 1: Al-Khalil/Hebron Road to Israeli Al Ja'abrah Prison.

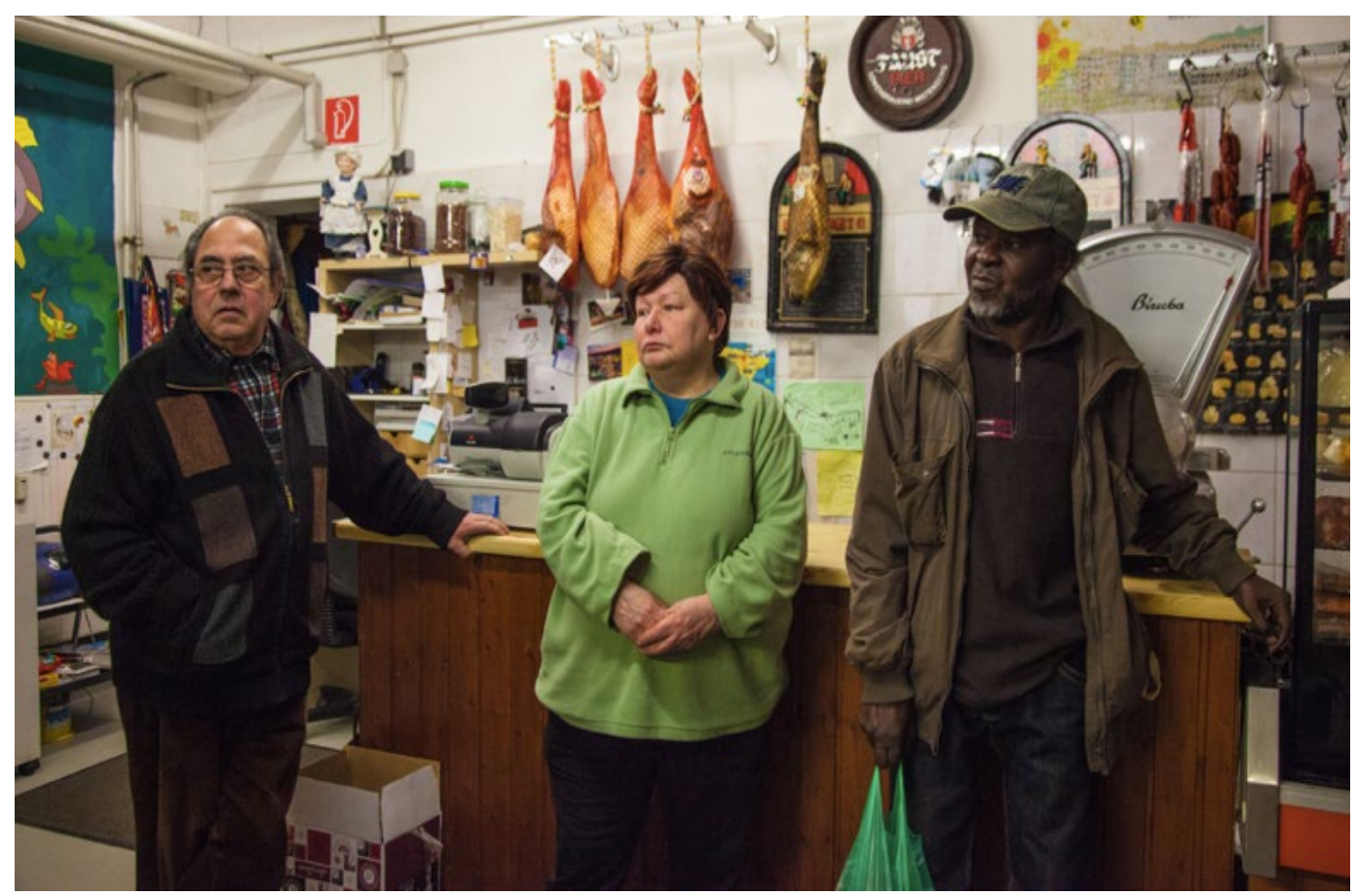

Figure 2: Kassel Grocery Shop.

By adopting the theme of 'home' rather than statelessness, stateless art interlocutors then inscribe their existence into European social imaginary. Portraying Palestine in terms of 'home' establishes the existence of Palestine as a home in the observers' perception, a nation not internationally recognised. Similarly, photographer Moussa Ag Assarid from Azawad, an unrecognised protostate in Mali, in his project 'The Revolution is without Frontiers' exhibits landscapes from Azawad draped in the Azawadian flag and signature of the National Movement for the Liberation of Azawad, which declared the 
independence of Azawad in 2012.15 Here, Ag Assarid adopts what Roland Barthes referred to as 'trick effects', where you use the objective mask of photography to represent something as truth and, in doing so, naturalise the existence of Azawad into our sensory experience. ${ }^{16}$ Also, the fact that these feature on the local architecture gives an idea of long-term permanence, as a building, permanent and difficult to demolish, prompts one to associate Azawad with enduring and stable features. With these two visual cues, Ag Assarid cements Azawad as a home that has a territorial reality, to an audience that may have disagreed before, due to its internationally unrecognised status. Moreover, this architecture does not stand alone but is accompanied by bustling communities, some of which are also wearing the flag on their clothes. In capturing this, Ag Assarid underlines not only that Azawad is a real entity, but that many people recognise it as 'home'. Here, Ag Assarid effectively reconfigures the European system of knowledge that Azawad is a failed proto-state, to the home of many proud Azawadians. In fact, Ag Assarid, in the interview, described his art as 'destabilising', acknowledging a concerted attempt to alter perceptions of Azawad. In doing so, Ag Assarid cements their existence as an ontologically real 'home', creating a space where he can negotiate for respect and recognition. Therefore, the arts show that despite being stateless, they too have a territorially bounded 'home', marking their existence into the European system of knowledge.

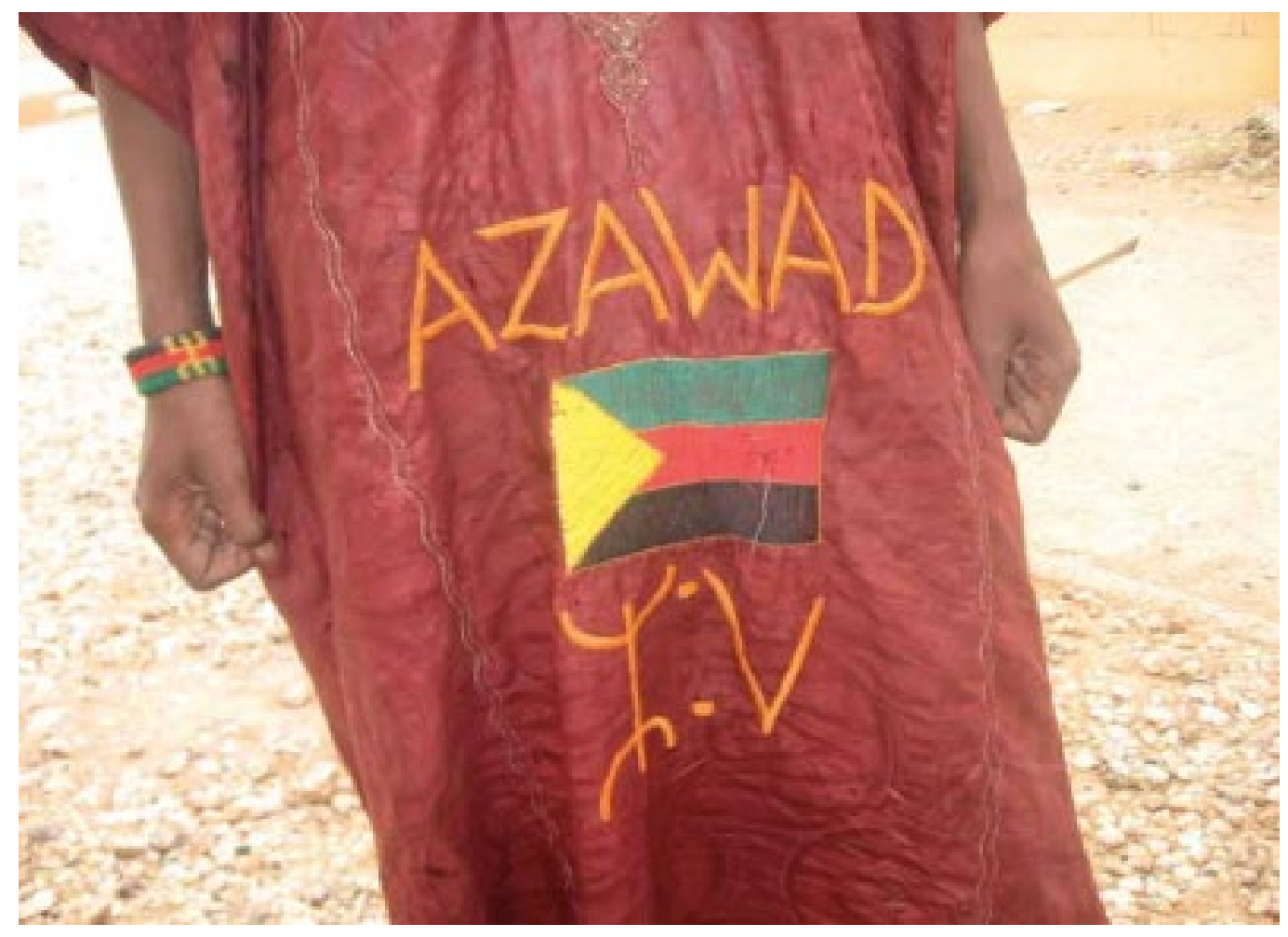

Figure 3: Azawad Flag on Clothes.

15 Moussa Ag Assarid 'The Revolution is without Frontiers' in Jonas Staal J and Moussa Ag Assarid (eds), The Art of Creating a State (Basis Voor Actuele Kunst 2014) $<$ http://newworldsummit.org/wp-content/uploads/2015/09/The-Art-of-Creating-a-State.pdf $>$ 140-73. See also Figs 3-5.

16 Roland Barthes, Image Music Text (Hill and Wang 1978) 21. 


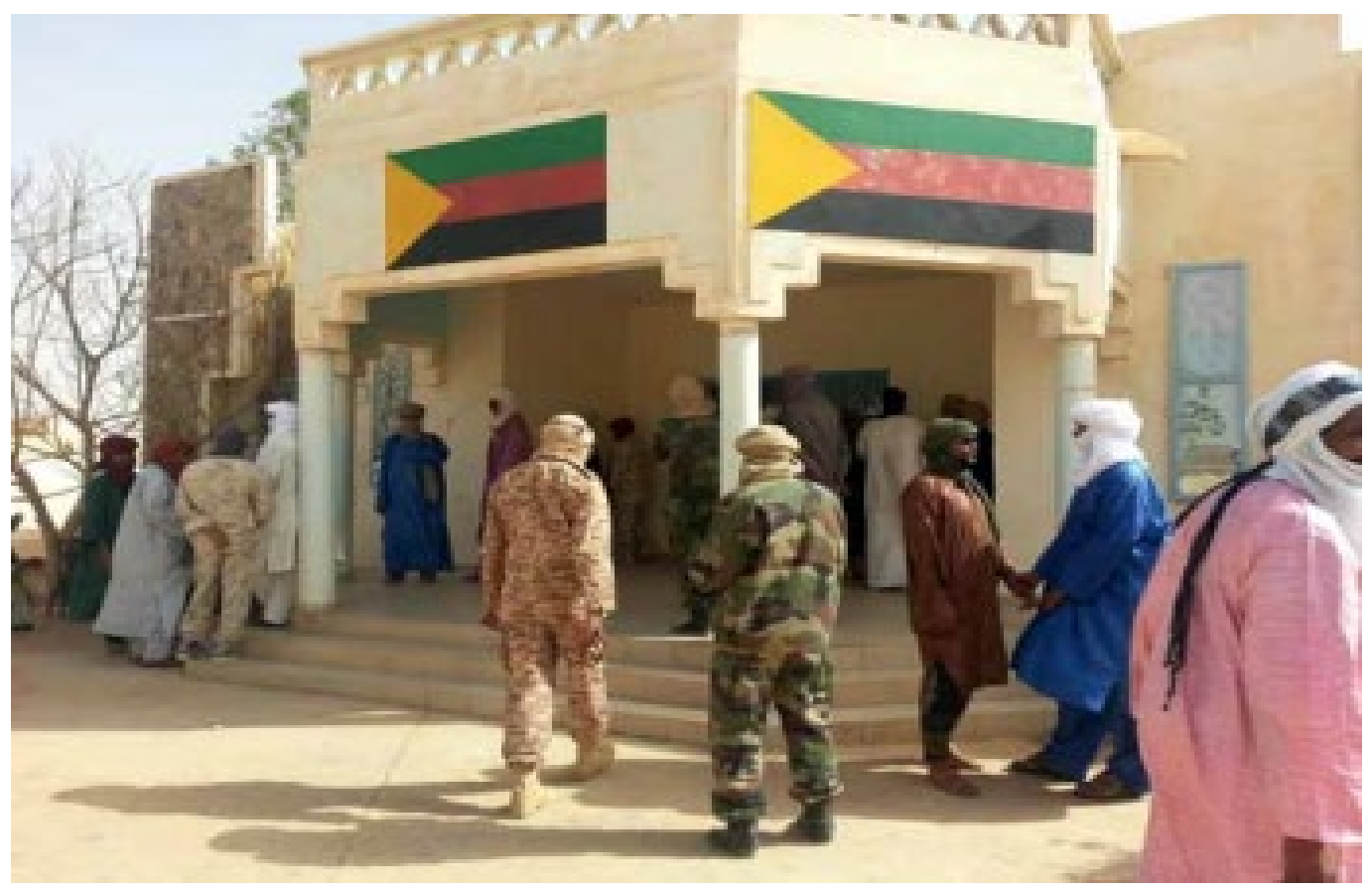

Figure 4: Administrative Centre in Kidal.

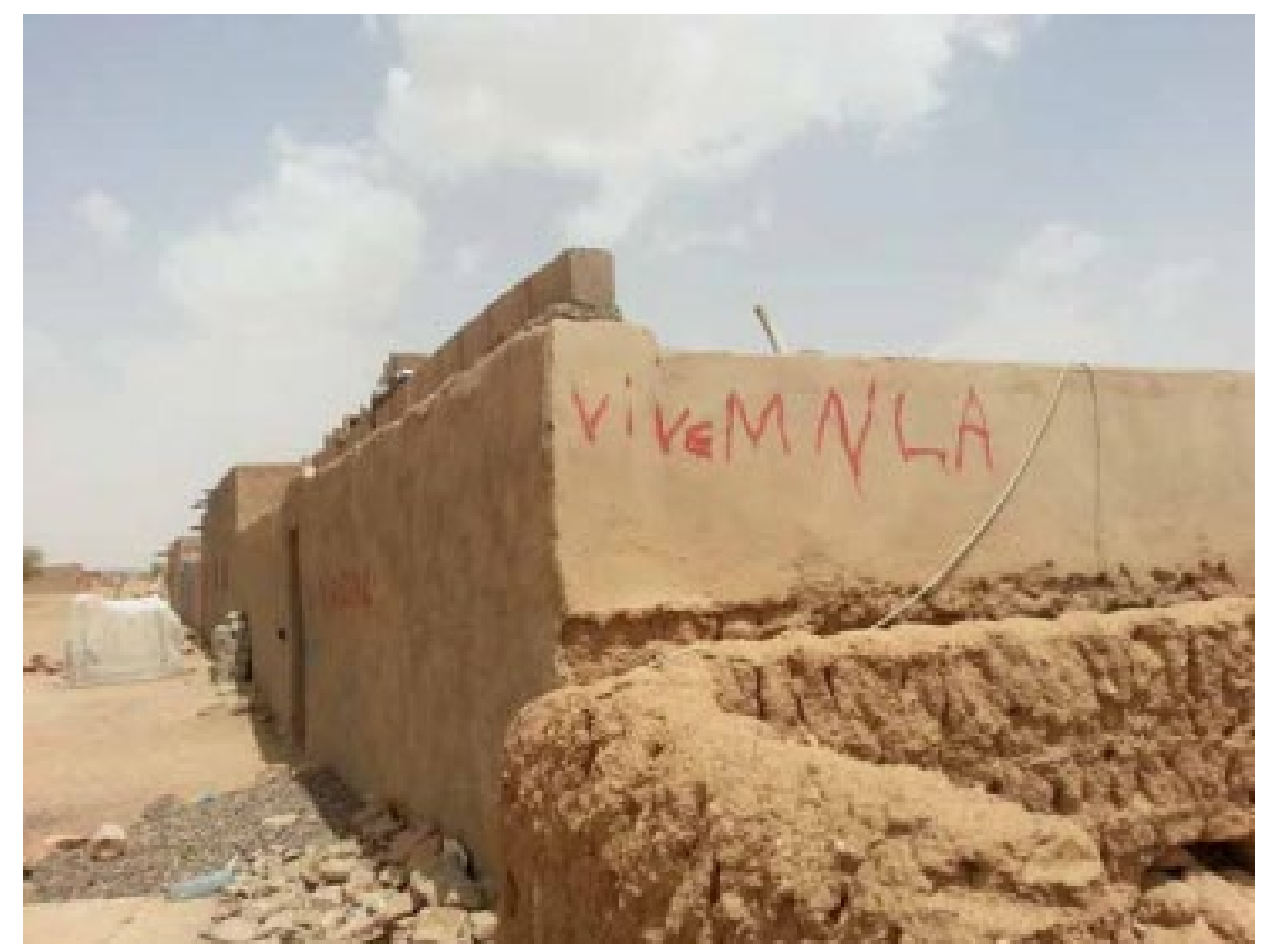

Figure 5: Graffiti in Kidal.

In contrast to the work of Shibli and Ag Assarid sewing the existence of their 'home' into European cultural libraries, Swaitat seeks to delocalise our understanding of home to show that it must not be tied to a state. Tendayi Bloom interestingly underlines how, in the discourse around statelessness, citizenship of a recognised state is constructed as the sole allocator of personhood and political 
existence. ${ }^{17}$ This then delegitimises the existence on the borderline, forcing stateless actors to be defined by a longing for citizenship to justify their existence. In Alien Land, Swaitat ridicules the notion of a sense of belonging believed to be inherent in a legal national identity, by emptying the term 'home' of meaning. 18 He does so in his play Alien Land, adapted from Emile Habiby's iconic sciencefiction novel The Secret Life of Saeed the Pessoptimist, where he tells the story of Saeed travelling with an alien, observing the lands and experiences he comes across as extra-terrestrial. ${ }^{19}$ Here, Swaitat ridicules our certainty of what space means, through the figure of the principal character Saeed, for example when he asks the audience: 'Do I look to you like someone from this planet?'. ${ }^{20}$ Through this, the term 'home' loses all ontological and territorial certainty. Yet, this existence on the borderline is one approached in terms of empowerment, rather than as a marker of vulnerability. This is seen in the chapter 'Saeed belongs', where he details his family legacy of displacement and living on the borderline. ${ }^{21}$ By affirming that this experience still means he is accorded a feeling of belonging despite not having a territorially bounded 'home', Swaitat shows an empowered permanence on the borderline. By reaffirming the existence on the borderline through the empty metaphor of 'home', an empathetic emotional and cognitive understanding of the comprehensive experience of statelessness is achieved. To be stateless is no longer merely a matter of sympathy for someone seeking recognition. By drawing parallels between the aspirational striving for a belonging to a 'home' as to that of a 'legal identity', stateless art interlocutors show that existence on the margins of the nation-state is not all that exceptional - allowing the audience to enter the imaginative experiential world of stateless peoples.

\section{UNIVERSALITY OF EXPERIENCE}

Statelessness is often set in counter-opposition to citizenship, creating an impenetrable boundary between the two social categories. Stateless art interlocutors use their art to navigate this binary, testing its limits. By building connections and discussing the idea of membership beyond the nation, they underline the universality of experience. They highlight similarities that deconstruct an understanding of stateless and non-stateless as inherently different. Nonetheless, artists also shed light on the importance of showing the differences of experience, to show how empathy must not erase difference.

Firstly, the Kurdish artist Shorsh Saleh spoke of feeling like a 'global citizen' and how he tries to reflect this in his art by championing an idea of membership beyond the nation-state. Indeed, Audra Simpson argues that currently our knowledge archive on 'membership' is structured through prior languages and experiences of exclusion. ${ }^{22}$ In fact, Saleh insisted that he wanted to use a style of miniature painting based on traditional Middle Eastern carpet motifs, with bright

17 Tendayi Bloom, 'Members of Colonised Groups, Statelessness and the Right to Have Rights' in Tendayi Bloom, Katherine Tonkiss and Phillip Cole (eds), Understanding Statelessness (Routledge 2017) 157.

18 Alien Land (n 1).

19 See Emile Habiby, The Secret Life of Saeed the Pessoptimist, tr Salma Khadra Jayyusi (Interlink Books 2001).

20 Alien Land (n 1) 2.

21 Habiby (n 19) ch 2.

22 Audra Simpson, Mohawk Interruptus: Political Life across the Borders of Settler States, (Duke University Press 2014) 9. 
colours and gold leaf, to keep the culture of his stateless population alive, whilst also portraying something that any European audience could relate to. ${ }^{23}$ The assortment of colours, with stripes of water motifs symbolising journeys across oceans and a paper boat, framed with gold, show a journey that is not only marked by vulnerability but by hope and beauty. As citizens of the world, whether migrating or stationary, anyone can see their own story in this painting, to show experience is not marked by a bounded territory we 'belong' to, but is universal.

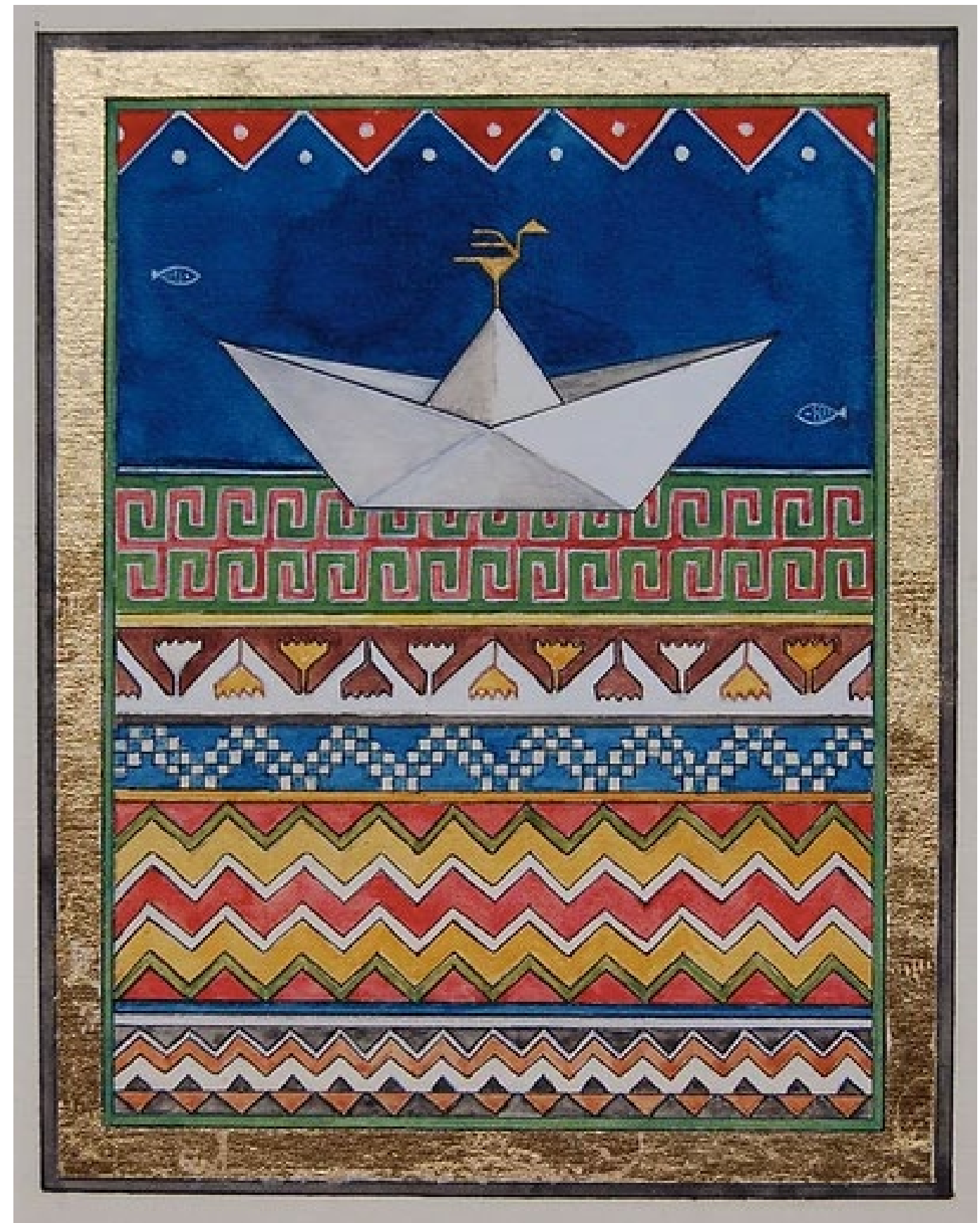

Figure 6: Migration.

23 See fig 6. 
However, is it necessary to be completely rid of the boundary between stateless and non-stateless to build empathy? Luisa Enria points out that eliciting empathy does not require an erasure of power differentials, rather it must coax us out of a false sense of comfort into constant problematisation and reflexivity. ${ }^{24}$ Indeed, whilst we must point to the similarities, one must not do this to the extent whereby one erases the stateless experience. Basel Zaraa, a Palestinian refugee that grew up in the Syrian refugee camp of Yarmouk, movingly displays this dynamic in his comic 'My Papers, My History'. Here, he narrates the experience of dealing with the United Kingdom Home Office at the border without a recognised travel document, namely the Palestinian travel documents accorded to Palestinian refugees in Syria. ${ }^{25} \mathrm{We}$ are immersed in Zaraa's troubling experience, as his character is drawn with a fence or darkness in the background, emphasising the difficulties. The final scene is a close up of his travel document suspended in a black background. ${ }^{26}$ This emphasis forces the reader to dwell on the luxury of being able to travel easily. Hereby, Zaraa reconstructs an 'us' of those who can travel with a recognised document and an 'Other' of stateless individuals who have difficulty travelling, which brightens the boundary between stateless and nonstateless individuals. When the clerk asks him why he has this document, he gives a detailed description of the 1948 expulsion of Palestinians into neighbouring countries, tying his personal experience directly to the larger geo-political context. ${ }^{27}$ Hereby, Zaraa establishes difference and forces the reader through this brightened boundary to problematise why it exists and how they feature within it, forging an empathetic connection. Therefore, the reader is forced to recognise this difference and problematise why it exists and how they feature in it, forging an empathetic connection through difference.

24 Luisa Enria, 'Co-Producing Knowledge through Participatory Theatre: Reflections on Ethnography, Empathy and Power' (2015) 16(3) Qualitative Research 319, 7.

25 Basel Zaraa, 'My Papers, My History', My Journey (Blog Post, 2014) ('My Papers, My History') $<$ http://myjourneymrc.tumblr.com/tagged/comics/>.

26 ibid 4. See also fig 8.

27 ibid 2-3. See also fig 9, 10. 


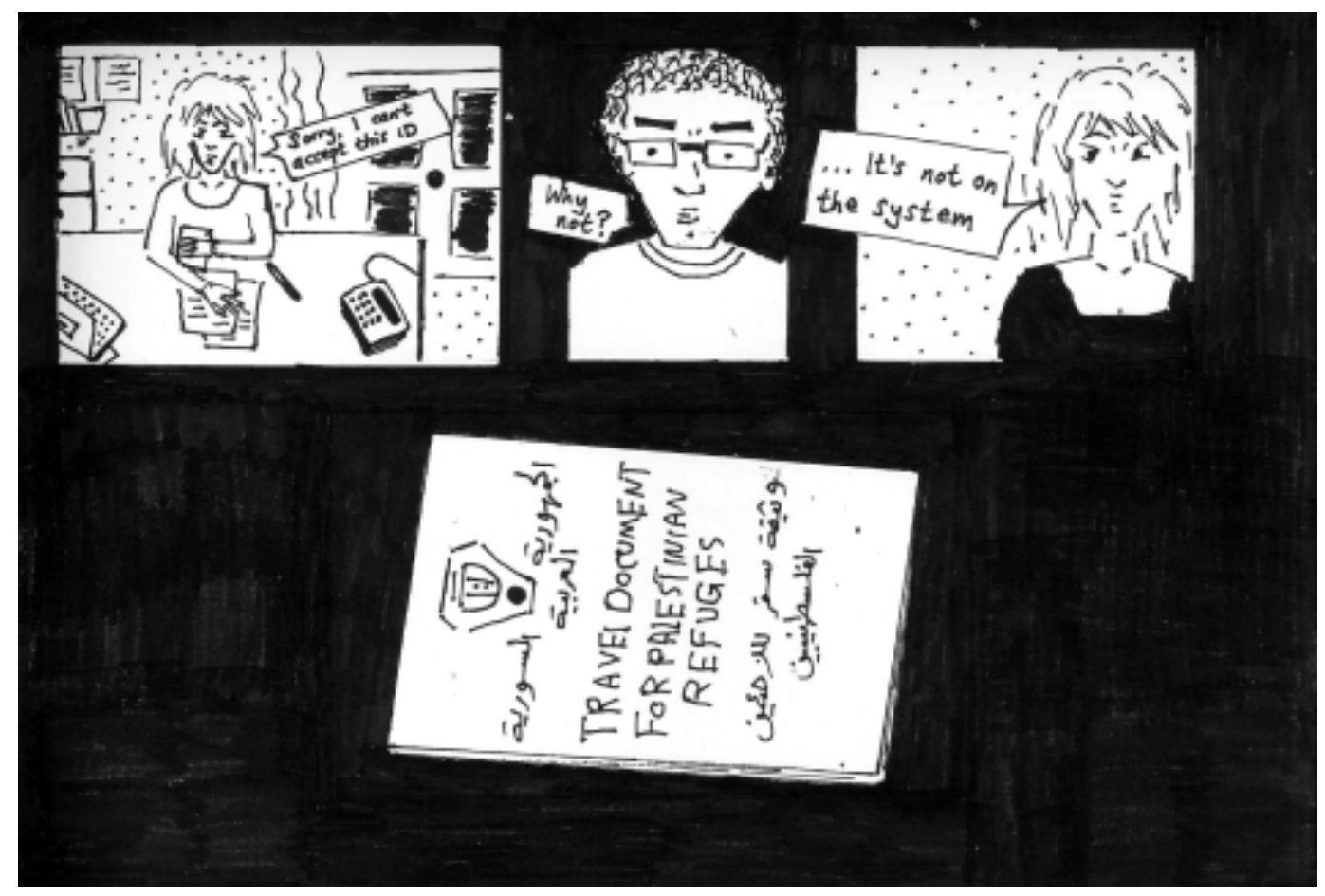

Figure 7: 'My Papers, My History' — Travel Document for Palestinian Refugees.

\section{COLONIAL LEGACIES}

The stateless art interlocutors, all stationed in Europe, use art to build a dialogue on Europe's historical colonial connection to the issue. Historical post-colonial ties linking European colonial empires to the creation of stateless populations show this deep European connection. Zahra Al-Barazi and Jason Tucker shed light on how, when the Middle East and North Africa were separated into nation-states under European colonial rule, they were largely split according to colonial divisions, creating a plethora of stateless populations. ${ }^{28}$ This was relevant for most regions across the world under colonial rule. In this context, the experiences of stateless populations are discussed as exterior to the European experience, only considered when defined by suffering worthy of European rescue. Therefore, stateless art interlocutors subvert this understanding of statelessness as fundamentally non-European, that evokes only pity for the stateless 'Other', evoking empathy rather than sympathy.

Firstly, stateless art interlocutors highlight these historical connections, indicating a European responsibility in the foundation of stateless populations. For example, Zaraa recounts a conversation with UK border guards: 'I told them your government is responsible for why I have this travel document', creating a link to European colonial history, Palestinian exodus, and his own personal plight. Indeed, Zaraa often switches from the collective 'we' of stateless Palestinians to 'I' to recall his personal experience, showing how closely intertwined he considers his own experience as a stateless individual to the geo-political history of his

28 Zahra Al-Barazi and Jason Tucker, 'Challenging the Disunity of Statelessness in the Middle East and North Africa' in Tendayi Bloom, Katherine Tonkiss and Phillip Cole (eds), Understanding Statelessness (Routledge 2017) 87, 88. 
region. He captures this closeness, and the relevance it has in the British context, in his art, where a whole page of My Papers, My History is dedicated to the 1948 Palestinian exodus. ${ }^{29}$ Therefore, Zaraa chooses to speak to a European audience, to open a dialogue with Europe about awareness of Europe's entanglement in the history of stateless populations. Empathy requires an immersion in the emotions and experiences of the Other, punctuated with reflexivity. Only with a sensitive awareness of history can an empathetic connection of the issue flourish, rather than a distanced one of pity.

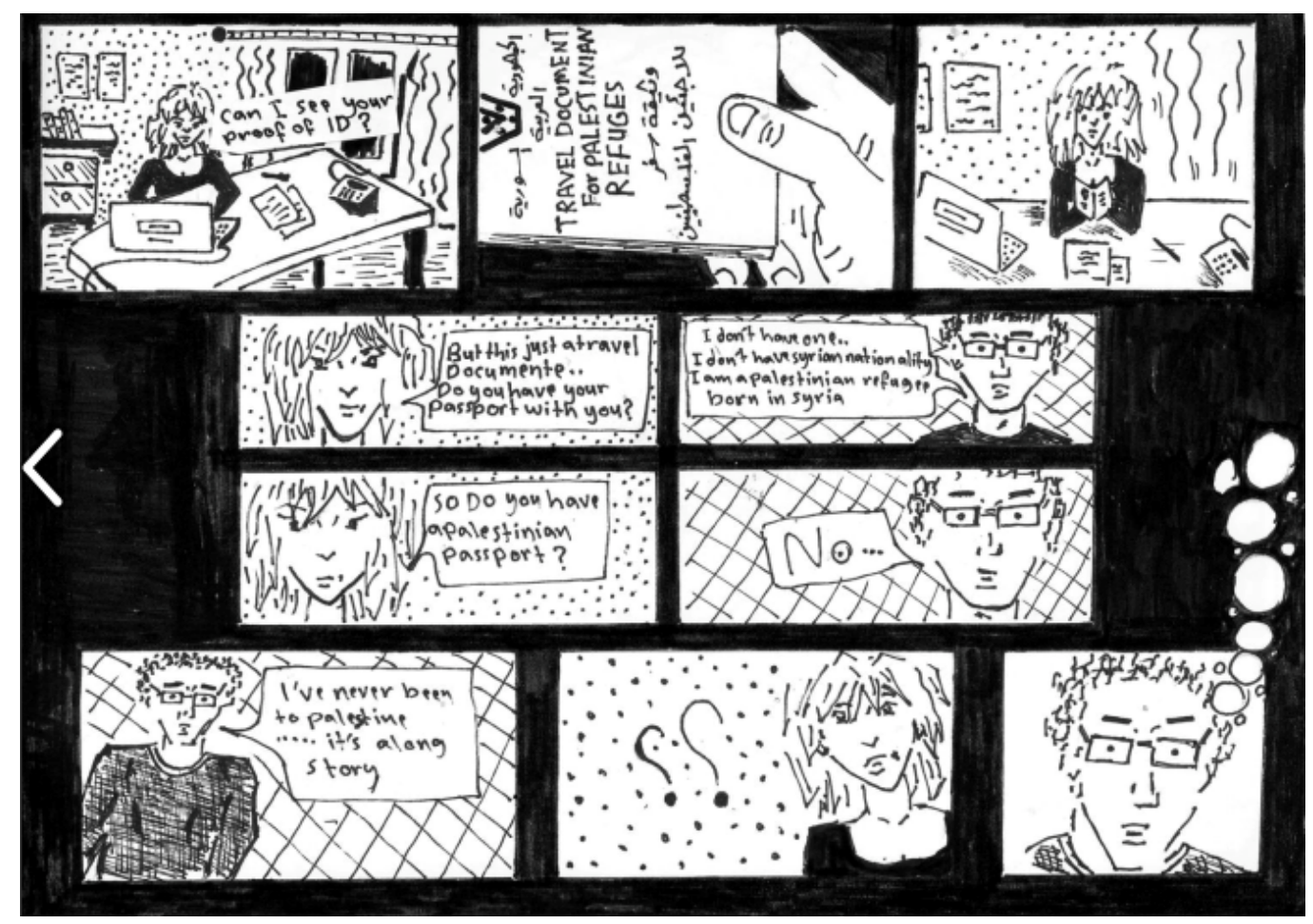

Figure 8: ‘My Papers, My History’ — 1948(1).

29 My Papers, My History (n 25) 3. See also Figs 7, 8. 


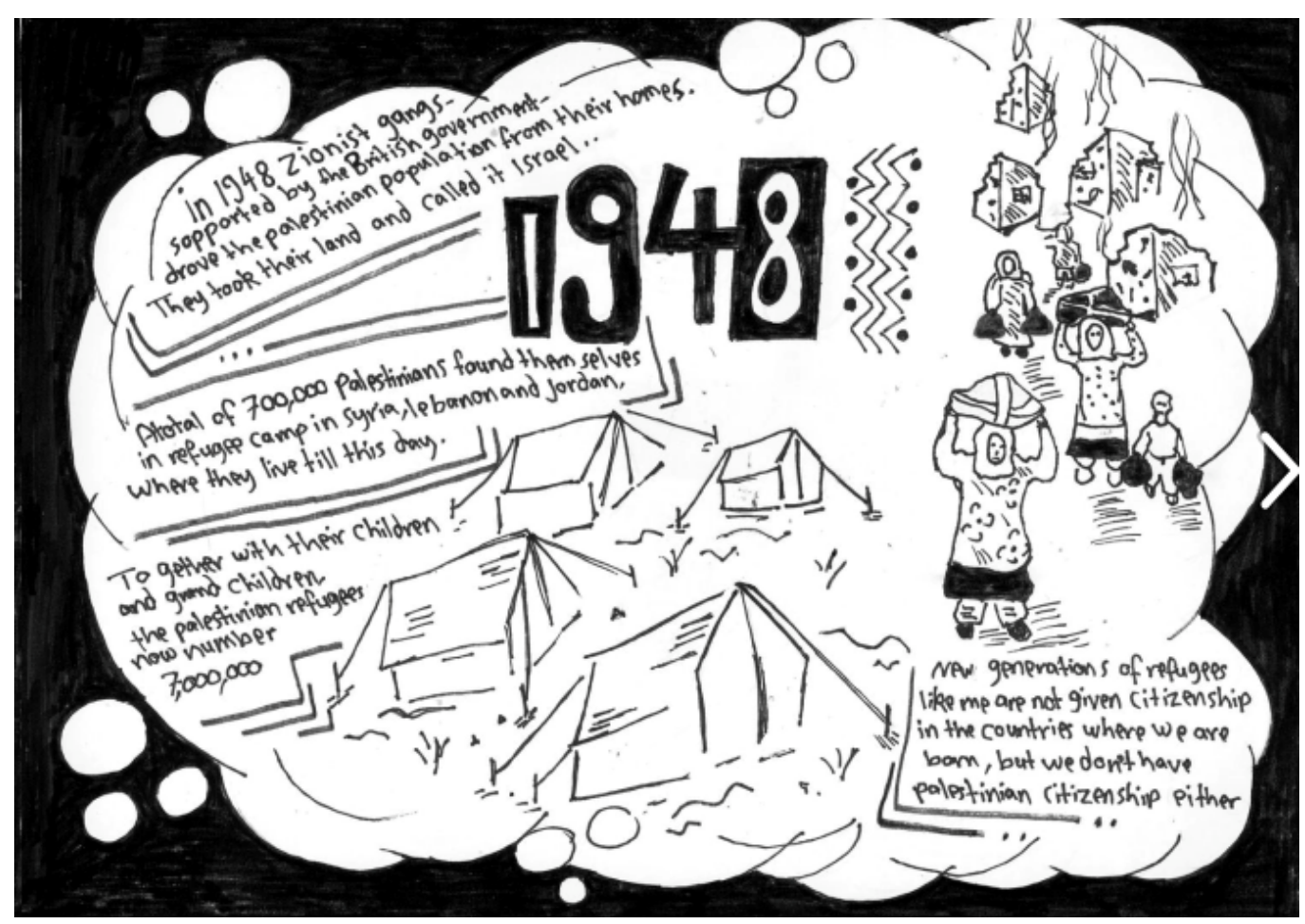

Figure 9: 'My Papers, My History’ — 1948(2).

Then, by giving stateless art interlocutors the agency to tell their own story, they break stereotypes of a long-standing discourse which marked statelessness solely by vulnerability. Aesthetically, this is constructed through a style theorised by Edward Said in Orientalism, establishing an ontological and epistemological distinction between 'the Orient' and 'the Occident', which justifies 'a style for dominating, restructuring and having authority over the Orient'. ${ }^{30}$ Swaitat in Alien Land tackles this head-on by opening with 'I invite you to come with me to a new universe - to the heart of the Oriental Imagination'. ${ }^{31}$ In doing so, Swaitat nods to the Orientalist gaze, and then proceeds to deconstruct it. For example, Saeed claims: 'I never fought over borders as some of you have accused me. And I never joined a political party, a military faction or the national army as your friends have suggested' ${ }^{32}$ By critiquing these Orientalist stereotypes and forcing the audience to reflect on their possible implication in them, Swaitat enables a deeper empathetic connection and understanding of statelessness, not just as a problem of the 'Orient'.

Moreover, stateless art interlocutors subvert the Orientalist discourse by rejecting its attempts to make stateless experiences only visible when they are stories of vulnerability. Miriam Ticktin coined the term 'Casualties of Care', when defining the victims of 'regimes of care' constructed in Europe, that allow those living on the margins of the nation-state to become visible only if they bring their stories of suffering to the forefront. ${ }^{33}$ Yet, stateless art interlocutors reject an understanding of statelessness as a vulnerability that needs European rescue. An

30 Edward Said, Orientalism (Penguin 2003) 3.

31 Alien Land (n 1) 1.

32 ibid 2.

33 Miriam Ticktin, Casualties of Care: Immigration and the Politics of Humanitarianism in France (University of California Press 2011). 
interesting example here is the poet Hassan Kosa from Balochistan, a region split between Iran, Afghanistan and Pakistan. He explains how his poetry encompasses messages of hope for the Baloch people, who endure persistent persecution, interspersed with messages of deep suffering and nostalgia. ${ }^{34}$ Yet, he refuses for his poetry to be translated into anything other than the indigenous Baloch language, for he believes his messages of suffering are not meant for a European audience. In doing so, Kosa refuses to be defined by suffering, and to put this feeling in the forefront to garner European attention. Thus, Kosa refuses to partake in the 'regime of care' and in doing so diminishes its importance, redirecting an understanding of statelessness away from one of intense vulnerability that elicits pity, and contributing to the establishment of a countering body of literature.
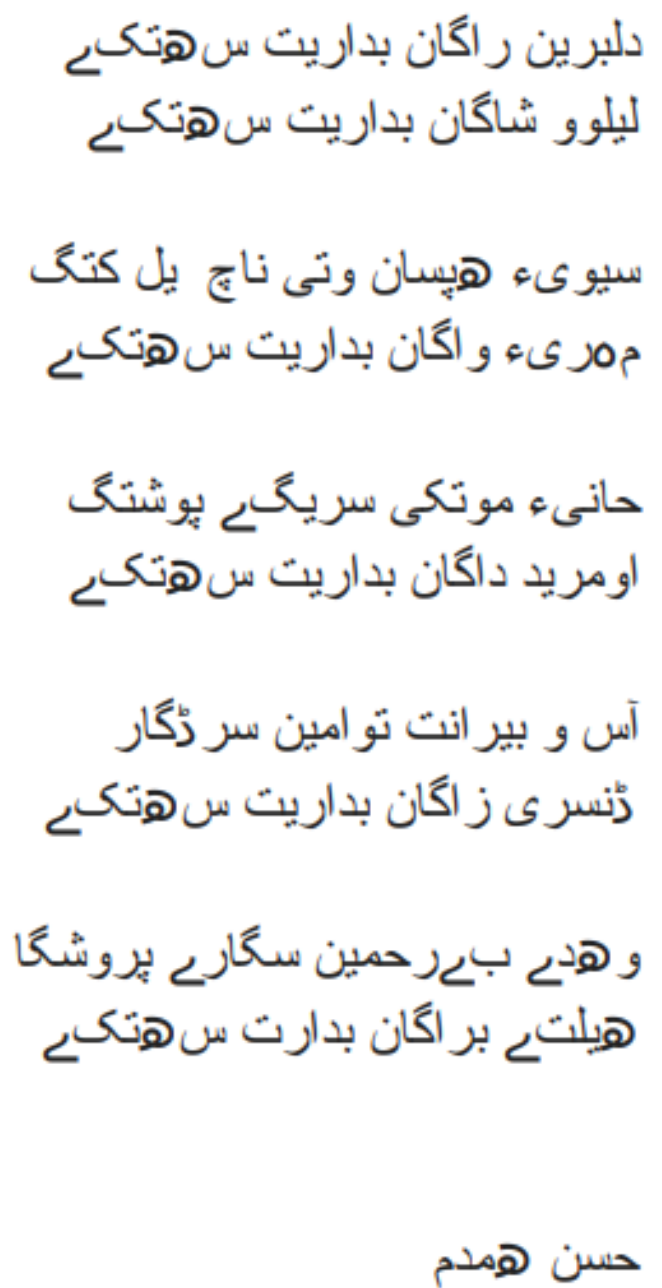

Figure 9: Hassan Kosa’s Poem.

34 'Hakkpaan and BHRO Publish Report on Enforced Disappearances in Balochistan' Unrepresented Nations and People's Organization (online, 2018) $<\mathrm{http}$ //unpo.org/article/21010/>, citing The State of Balochistan's Human Rights (Bi-Annual Report, Human Rights Council of Balochistan and Baloch Human Rights Organization 2018). 


\section{CONCLUSION}

Stateless art interlocutors are reclaiming the discourse on statelessness through their creative productions. By reshaping and contesting statelessness to elicit an empathetic connection, they effectively reshuffle the European, and potentially global, system of knowledge on statelessness. First by rejecting the term and redefining it in terms of an ontologically real or delocalised 'home', then by shedding light on the universality of experience that exposes that membership must not be based on nation-state boundaries. Finally, stateless art interlocutors reflect on the colonial legacies of their plights, shedding light on historical connections and breaking colonial stereotypes that define stateless peoples as victims worthy of European rescue. This dissents from the discourse of statelessness as a 'curse' to be eradicated. Whilst still acknowledging statelessness as a source of torment and pain due to the context of becoming stateless being one of exile and conflict, and the anguish potentially contingent in a lack of a national identity, it does so in a dignified, empowering manner allowing affected populations a voice and agency. This is a perspective that must be taken into account in policy-circles. Through the arts, policy-makers can not only listen to the lived experience of affected populations, but be immersed in their experiential world. Moreover, others can become involved to help bring attention to statelessness in the arts: follow your local galleries, and urge them to support artists working on statelessness, and to include these voices in their collections. The radical empathy fostered in these artworks makes statelessness harder and harder to discard - leaving an indelible mark in our minds. Swaitat's initial lesson rings truer than ever; he disappeared but he did not die - we must not let his story and that of other stateless art interlocutors slip through the cracks.

In 2018 the Statelessness \& Citizenship Review had an open call for artworks responding to the Review's focus on advancing understandings of statelessness and citizenship phenomena and challenges. ${ }^{35}$ The winning artwork Critical Mass by Wasim zaid Habashneh beautifully ties together many of the themes and styles adopted by the stateless art interlocutors I worked with, of home, global community, unity in difference and the universality of experience. The piece, created using a traditional Jordanian sand art in discarded fluorescent tubes with pixelated patterns, incorporates Habashneh's architectural background in its composition moulded with larger concepts of home, belonging and identity. Critical Mass means the sufficient number to achieve a result - here Habashneh uses this as the title to prompt the question: what makes civil society? Critical Mass seems to resemble the shape of a world map, with the moving tubes structured with different slithers of colour. This alludes to a global community, whilst also delineating difference in the different colours. This also underlines how stateless people and non-citizens are equally as deserving of belonging in a global community, but should not have to erase their identity to become a part of it. Moreover, the motion of the tubes importantly signifies how societies are not static but are in fact always changing. In fact, what statelessness is and how it configures in societies will always be changing, much like shown by the fluid component of sand. Habashneh opens up our understanding of identity and belonging as territorially marked and fixed, but as always changing and able to incorporate

35 The artwork can now be found on the Statelessness \& Citizenship Review's website. See Statelessness \& Citizenship Review (Web Page, 2018) $<$ https://statelessnessandcitizenshipreview.com/index.php/journal>. 
stateless people and non-citizens, often excluded and considered anomalies. Critical Mass shows us how our perception of who and what makes a society must remain fluid and open to what the 'critical mass' for it to flourish is. Especially one that leaves no one behind. 